L'HOMME L'Homme

187-188 | 2008

Miroirs transatlantiques

\title{
One for the Money, Two for the Show
}

On Postcolonial Studies and South Asian History

Sanjay Subrahmanyam

\section{(2) OpenEdition}

\section{Journals}

Electronic version

URL: https://journals.openedition.org/lhomme/29212

DOI: 10.4000/lhomme.29212

ISSN: 1953-8103

\section{Publisher}

Éditions de l'EHESS

\section{Printed version}

Date of publication: 3 October 2008

Number of pages: 93-104

ISBN: 978-2-7132-2186-6

ISSN: 0439-4216

Electronic reference

Sanjay Subrahmanyam, "One for the Money, Two for the Show", L'Homme [Online], 187-188 | 2008,

Online since 01 January 2010, connection on 23 April 2022. URL: http://journals.openedition.org/

Ihomme/29212 ; DOl: https://doi.org/10.4000/Ihomme.29212 
chercher : repérer : avancer

Cet article est disponible en ligne à l'adresse :

http://www.cairn.info/article.php?ID REVUE=LHOM\&ID NUMPUBLIE=LHOM 187\&ID ARTICLE=LHOM 1870093

One for the Money, Two for the Show. On Postcolonial Studies and South Asian Hist ory

par Sanj ay SUBRAHMANYAM

| Éditions de l'EHESS | L'Homme

$2008 / 3-4-n^{\circ} 187-188$

ISSN 0439-4216 | ISBN 9782713221866 | pages 93 à 104

Pour citer cet article :

- Subrahmanyam S., One for the Money, Two for the Show. On Postcolonial Studies and South Asian History, L'Homme 2008/3-4, n 187-188, p. 93-104.

Distribution électronique Cairn pour les Éditions de l'EHESS.

(C) Éditions de l'EHESS. Tous droits réservés pour tous pays.

La reproduction ou représentation de cet article, notamment par photocopie, n'est autorisée que dans les limites des conditions générales d'utilisation du site ou, le cas échéant, des conditions générales de la licence souscrite par votre établissement. Toute autre reproduction ou représentation, en tout ou partie, sous quelque forme et de quelque manière que ce soit, est interdite sauf accord préalable et écrit de l'éditeur, en dehors des cas prévus par la législation en vigueur en France. Il est précisé que son stockage dans une base de données est également interdit. 


\section{One for the Money, Two for the Show On Postcolonial Studies and South Asian History}

Sanjay Subrahmanyam

- Shallow: Give me pardon, Sir: if, Sir, you come with news from the court, I take it there is but two ways: either to utter them, or to conceal them. I am, Sir, under the King, in some authority.

— Pistol: Under which king, Bezonian? Speak, or die.

— Shallow : Under King Harry.

— Pistol : Harry the Fourth? or Fifth?

- Shallow : Harry the Fourth.

- Pistol: A foutra for thine office!

Shakespeare, Henry IV, Part 2 (Act V, Scene 3).

LET ME BEGIN with an extended anecdote that will serve here as a form of casual ethnography. Some years ago, while at an American university, I attended a « job-talk» a lecture which, though intended above all for members of a department that is seeking to recruit someone, is open to the public at large. These are peculiar affairs, largely unknown on the other side of the Atlantic, although they have now begun to penetrate England on the rare occasion, in places like Brighton; they are still unheard of though for the most part in Paris, Oxford or Lisbon (or for that matter Delhi or Chennai). At the risk of producing ennui, let me briefly summarize my sense of how these work. The American (and Canadian) "job-talk» normally is a part of a larger ritual. It can broadly take two forms. The first, and statistically less common, one is when there is a «target-ofopportunity " search, which is when the host university is in fact courting the candidate. On such occasions, the job-talk is largely a formality and will often be quite poorly attended because its outcome is already known, unless of course the candidate manages to disgrace himself beyond all measure. The talk itself is surrounded by all sorts of other rituals : breakfast, lunch and dinner meetings with individuals or small groups (the Quadrangle Club at the University of Chicago is fascinating as an ethnographic site from this point of view, suggesting that David Lodge was more reporter than satirist); short conversations with graduate students en brochette; appointments for the candidate with deans and provosts; a reception or two with wine and cheese; and a dinner the quality of which will often depend on the perceived importance of the candidate. I was once present when, on account of the candidate's alleged status, the puissance invitante was the President of the university and the usual budgetary restrictions were thrown to the winds. But the case I am about to describe belonged to the other, more common, category. The candidate was a younger man, trained in the 
United Kingdom. There was clearly a certain amount of scepticism in the air about him. It was clear that even a good performance might not suffice to get him through. It was hard for an outsider even to gauge the depth of the waters.

In the event, the actual performance was very polished. There was proper shamanistic ritual in the use of Power Point. The speaker stood at a podium as he spoke, and used a text to read from, which Americans often prefer not to do as it suggests they do not quite master their materials. This, as much as his accent, marked him out not only as someone who came from the other side of the Atlantic, but as one who had been wholly trained there. (British academics who wish to show their familiarity with the US after having spent some time in the country will often make gratuitous references to baseball, or use what they imagine are deep American expressions such as: "That's the way the cookie crumbles", or "That's the good news; now here's the bad news»). But in this case the use of the written text was deft, and eye-contact with the audience was surprisingly good. The applause was generous, and the time eventually came for questions and answers. Sipping water, the candidate was clearly relieved at his own performance and was now somewhat off-guard. A smoker, he had clearly not read what a standard guide to job-talks suggests : "Try to be in good physical condition ; long-distance running or some other types of stamina-development would probably be good preparation for this challenging stage of the search " (Thomas 1989: 322). The questions began, and it was immediately clear that they were entirely different from those in a British seminar room. No empirical materials were discussed. Archives and documents were not even mentioned. The subject was colonial India and British rule there, and it became clear that the most pressing question that bothered people in the room was the nature of the candidate's own identity. Finally, a questioner from outside the history department, but self-professedly linked to the current known as Postcolonial Studies, raised his hand. "There are now two schools in Indian history", he declared confidently, "Subaltern Studies, and the Cambridge School. I would like to know where you are located in relation to these two". The candidate was nonplussed. He had some degrees - though not his doctorate - from Cambridge, but the work was extensively based on vernacular-language materials from India, not normally the case in Cambridge; the perspective was very much that of a sort of classic social history, which historians of Europe could readily identify with. He attempted to evade the question, stating that he did not believe in such self-identifications. The pursuit became hotter, and the visitor became more uneasy. Eventually, a real cloud settled over the room. The next day, in the corridors, all the talk was about how the candidate had failed adequately to identify himself. This was clearly unacceptable. Pistol, Shallow and especially Falstaff in Shakespeare's Henry $I V$ would have understood.

I often wonder how - esprit de l'escalier aside - I myself would have responded in such a situation, and I shall attempt to answer the question in closing this short essay. But a brief history of how a situation such as the one I have just described came to arise may be worthwhile. The two key oppositional 
terms that were in use above were "Cambridge School" and "Subaltern Studies", and in a sense they do together comprise a miroir transatlantique of sorts. But such was not always the case. It is simply that the status of the third party in the equation, namely India, has diminished radically and almost disappeared. Now the "Cambridge School " in relation to the historiography of India and South Asia is a notoriously slippery object. It should not be confounded with at least two other "Cambridge Schools»: that associated with Quentin Skinner, John Dunn and the analysis of the history of political ideas (or «texts in context»); and that associated with Joan Robinson and a form of leftist political economy. The India-related Cambridge School is variously associated in its foundation with figures such as John Gallagher and Eric Stokes, and continued with Anil Seal, and a whole host of others such as Gordon Johnson, Brian R. Tomlinson, and Christopher Baker, who often published both essays and acerbic book reviews in the journal Modern Asian Studies, which was created in the mid-1960s (Subrahmanyam 2002). The « school» never wanted clearly to identify itself as such. It was instead identified in those terms by its targets and primary opponents, namely nationalist Indian historians who had written in the 1950 s and 1960s of matters concerning the Indian national movement. The purpose of the Cambridge historians was seen as demystifying Indian nationalism, cutting the heroic mythical figures of the national movement down to size, and stressing the extensive collaboration of "native " elites in the running of the British Empire in India. A part of this was Lewis B. Namier's notion of politics as really the affair of men in smoke-filled rooms, but the thrust was clearly to stress the importance of interests over ideologies. In this process, British official papers and documents were diligently mined, but none of the historians trained in Cambridge (or Oxford) in the 1960s seem to have paid particular attention to sources other than those in English.

Subaltern Studies on the other hand, did identify itself as a project, and was self-consciously run somewhat like a journal by a collective of Indian and (a few) British historians, initially based (to 1988) in India, the United Kingdom and Australia. It emerged in the late 1970s, and was initially linked with Maoist student politics in India, though it appears to have crystallized when a number of key figures such as Ranajit Guha (born in 1923, and a clear generation older than the others, who were really his disciples), Gyanendra Pandey, and Shahid Amin found themselves together in first Delhi and then England. At this point, there was nothing trans-Atlantic at all about it, save that Guha was paradoxically funded by the Ford Foundation in India for a certain time. There were no American passport-holders or even academics who taught in the United States in the founding collective ; in the 1970s, this would have probably been quite unacceptable in the context of the Vietnam War. In its initial incarnation, Subaltern Studies targeted both Indian nationalist historiography and the Cambridge School, alleging that both were profoundly elitist in their bias. The experience of common folk - peasants, workers, tribal peoples - had been neglected by them in favour of a narrative where the high politics of the British-Indian encounter 
was the focus. There was no emphasis by Guha and others though on using vernacular sources; it was simply pointed out that even the official British sources could be read differently, in a manner that was sympathetic to the "subaltern" classes. Thus, even historians who worked solely with Englishlanguage official materials, such as David Arnold, participated in the project, so long as they shared a broadly anti-elitist stance. It was a question of having your heart in the right place in regard to class politics; such thorny issues as gender had not yet entered the picture.

The rapid, enormous and somewhat astonishing success that Subaltern Studies enjoyed in the first half of 1980s (after its first volume came out in 1982) meant that it came almost immediately to attract the attention of established historians based in America, who up to that point had largely been left out of an argument that was organized on a Britain-India axis. At this time, the leading figure by far in the US was the Chicago-based Bernard Cohn, a left-leaning figure who was more comfortable with the essay than the monograph as a form of expression, and who had long proposed a meeting ground between anthropology and history in the context of South Asia. Cohn's rivals for intellectual leadership in the matter of Indian history in the US were few : the chief one was Burton Stein, himself a Marxisant radical (who sometimes described himself mock-seriously as an " anarcho-syndicalist»), who after teaching in Minnesota and Hawai'i, had decided in the 1980s to retire early to London, where he claimed he found the radical politics more to his taste than in his native United States. They also included clearly conservative figures with a missionary background such as Robert Eric Frykenberg at Wisconsin ; and then there were also far more elusive historians such as Thomas Metcalf at Berkeley, and Ainslee Embree, a Canadian-born American who taught at Columbia. But it was Cohn who, at the prestigious University of Chicago, had the most loyal following and had trained the largest number of students. Both Cohn and Stein were clearly attracted initially to Subaltern Studies, but it was an essay by the former that eventually appeared there (as "The Command of Language and the Language of Command ») (Cohn 1985). It appeared at a moment when American universities were beginning to emerge as alternatives to Oxford, Cambridge and London, as destinations for young Indian students wishing to do a doctorate. Stein's own essay of the time on peasant insurgency in Mysore, published in a far more obscure place in the same year as that of Cohn, took a much more critical tone with regard to Guha and Subaltern Studies. He concluded: "Guha's purpose of bringing events and processes relating to peasant insurgency under serious historical analysis is correctly conceived and defended ; I suggest here that his method is not " (Stein 1985 : 27). The essay was quickly forgotten, while Cohn's on the other hand came to acquire a certain prestige. I can remember the sense of pleasure and pride with which some members of the Subaltern Collective told me - I was then a doctoral student in Delhi - that even the heavyweights of the American academy were now negotiating with them, and that while some of their essays were being accepted, others were being summarily rejected. It was a heady postcolonial moment of sorts I suppose. 
The reaction by the mainstream of Indian nationalist historians, whether those attached to the centre-left Congress or the more Stalinist CPI (M), to Subaltern Studies was immediate and violent. One can see this in the pages of an official magazine such as Social Scientist, and the acid comments of iconic Marxist-nationalist historians like Irfan Habib (Singh et al. 1984; Habib 1995). This rejection continues in many respects, and essentially consists in the main of accusing Subaltern Studies historians either of shallow romanticism, or of a radical culturalism that shares many traits with the far right-wing Hindu trend in Indian politics. (Later Subaltern Studies devotion to the figures of Nietzsche and Heidegger has really not helped matters in this respect). The reaction from Cambridge was more complex. The early figures of prestige, Gallagher or Stokes, were not active by this point in the 1980s, and Anil Seal and Gordon Johnson did not respond either. A concrete response eventually came from Christopher A. Bayly, who by the 1980s - after having spent years as a marginal, often unshaven, somewhat cynical figure in a leather jacket - was slowly and suavely emerging in a proper jacket and tie as the dominant figure in Cambridge, although he usually claimed discomfort with the "Cambridge School» label. Bayly had worked initially, like most of his contemporaries, on the Indian national movement (in his case, in the northern Indian town of Allahabad); but from the late 1970s he had decided to shift his attention to a far earlier phase, that of early colonial rule under the East India Company beginning in about 1770 . This move, in which he was soon to be followed by his close colleague, David Washbrook, meant that Bayly was by 1985 not really a central participant in debates on Indian nationalism and the critique thereof. His response to Subaltern Studies was hence muted, and consisted of a brief essay pointing out that much of what Subaltern historians claimed to innovate in had already been set out by the best-known of British radical historians such as Eric Hobsbawm or Edward P. Thompson (Bayly 1988). It was really a rather dismissive reaction, rather than a deep form of intellectual engagement. In contrast, in the same year, 1988, Rosalind O'Hanlon, a social historian at Cambridge who had in no way been identified with the erstwhile "Cambridge School " and who worked on lower-caste movements in western India, emerged with a wide-ranging but broadly appreciative critique, pointing to conceptual blind-spots and lacunae in Subaltern Studies (O'Hanlon 1988). Rather than a bipolar field defined by a Subaltern-Cambridge axis of tension, what appeared to have emerged in about 1990 was an interesting form of fragmentation, with Subaltern Studies being the centre of attention where late colonial questions were concerned, but largely absent in regard to studies of pre-1900 India. Many debates of the time centred on quite distinct questions; there was for example a rather violent set of exchanges between historians of India on the one hand, and Immanuel Wallerstein and his disciples on the other, on the matter of "world-systems theory " and its applicability to India ; while another central figure was the British Marxist historian Frank Perlin, who in a series of exciting essays proposed a radical reconsideration of the political economy of the XVIII ${ }^{\text {th }}$ century. "Under which king, Bezonian? Speak, or die». This was hardly the issue then. 
It was at this point however that trans-Atlantic geopolitics came to play a decisive role. It is usual to identify this with the so-called "Phase Two " of Subaltern Studies, often dated to about 1988 and the supposed engagement of the Subalternists with postmodernism. Dipesh Chakrabarty, who in recent times has become somewhat the official historian of Subaltern Studies, describes matters as follows, in a remarkably bland tone :

"[Ranajit] Guha retired from the editorial team of Subaltern Studies in 1988. In the same year, an anthology entitled Selected Subaltern Studies published in New York launched the global career of the project. Edward Said wrote a foreword to the volume describing Guha's statement regarding the aims of Subaltern Studies as "intellectually insurrectionary”. Gayatri Spivak’s essay Deconstructing Historiography (1988), published earlier in the sixth volume under Guha's editorship in 1986, served as the introduction to this selection. This essay of Spivak's and a review essay by Rosalind O'Hanlon (1988) published about the same time made two important criticisms of Subaltern Studies that had a serious impact on the later intellectual trajectory of the project. Both Spivak and O'Hanlon pointed to the absence of gender questions in Subaltern Studies. They also made a more fundamental criticism of the theoretical orientation of the project. They pointed out, in effect, that Subaltern Studies historiography operated with an idea of the subject - "to make the subaltern the maker of his own destiny" that had not wrestled at all with the critique of the very idea of the subject itself that had been mounted by poststructuralist thinkers. Spivak's famous essay Can the Subaltern Speak? (1994), a critical and challenging reading of a conversation between Michel Foucault and Gilles Deleuze, forcefully raised these and related questions by mounting deconstructive and philosophical objections to any straightforward program of "letting the subaltern speak" "(Chakrabarty $2000: 24)$.

This is a rather peculiar and narrow framing through of a history of ideas, shorn of any institutional or other context. It is as if the critiques that Roland Barthes had laid out much earlier, in the late 1960s, suddenly appeared full-blown two decades later on the consciousness of Subaltern Studies historians; the death of the sovereign subject, the death of the authorial voice, and of agency itself - issues that historians in France had grappled with and also come to terms with - ostensibly became the occasion for an extended bout of hand-wringing. Had such self-doubt about the future of history and historical practice been the real basis of a programme, it could hardly have been one charged with much selfconfidence. This makes one wonder. What then might the real context be that led from the diverse and dispersed field of 1988 to an imagined landscape where only two strong and self-assertive poles exist: Subaltern Studies and the Cambridge School? We must turn to the debates of the early 1990s and their larger framing to comprehend what really transpired. The central debate is undoubtedly that which took place in the pages of the Ann Arbor-based journal Comparative Studies in Society and History between Gyan Prakash on the one hand, and Rosalind O'Hanlon and David Washbrook on the other (Prakash 1990, 1992 ; O'Hanlon \& Washbrook 1992). It is here that one finds the origins of the imagined Cambridge-Subaltern duopoly. This is how the debate ran. 
Prakash had not long before finished his doctoral dissertation on landless labour in Bihar, and the spirit cults associated with those who had died a bad death at the hands of a landlord. The work was much admired; it was also less in the spirit of Subaltern Studies than of James C. Scott, the historian and political scientist at Yale who celebrated everyday forms of resistance. However, in the late 1980s, Prakash became the central figure in nudging Subaltern Studies into an initially post-structuralist (and then increasingly post-modernist) mode, or what would by 1994 be clearly termed « Postcolonial Studies » or « Postcolonial Criticism " (Prakash 1994). This meant weaning Subaltern Studies away, once and for all, from the social-history tradition of Thompson and Hobsbawm to which Bayly had insistently claimed they belonged. It also meant largely abandoning the fading field of economic history. Henceforth, culture would lie at the heart of matters. In other words, for Subaltern Studies to enter the United States academy in force, it had in effect to take the "cultural turn " and that too in no half-hearted way. If not, it would be indistinguishable from the run-of-the-mill of Latin American peasant studies. There were peasant rebellions aplenty between Nicaragua and Bolivia; a few more in Bihar or Andhra would not change matters. Product differentiation was now of essence, and Ranajit Guha could not be confused with Subcomandante Marcos. In other words, as oral tradition would have it, if Gayatri Spivak can be likened to Ry Cooder, Subaltern Studies at this time should be compared to Buena Vista Social Club.

This was a moment, let us recall, of a global reorientation in Indian studies. The "old powers" were beginning to fade somewhat. The shine had definitely gone off Indology in France and Germany, and Indian studies in England were also in some disarray (Subrahmanyam 2000). In India, the early 1990s saw the first major attack on university funding, and led under liberalization to the progressive collapse of major departments in the social sciences that has gone on ever since. In Pakistan the situation was by then truly disastrous in history and the social sciences; the Sri Lankan universities such as Peradeniya, which had once enjoyed an excellent reputation, were also in some difficulty. On the other hand, the market for India in the United States was on the upswing. The "heritage » students, those of Indian origin, were just beginning to emerge as a force. Liberalization in terms of foreign exchange availability would eventually permit more and more Indians to send their children abroad to study in universities. The great American universities and liberal arts colleges were beginning to wake up to the possibilities, leading to the veritable explosion in Indian studies positions that has resulted since. (In 2006-2007 alone, by my count, there were at least 15 new positions in Indian history in consequent US universities and colleges; the numbers for 2007-2008 seem comparable). Once, in the 1960s and 1970s, India had been the monopoly of a small cartel of centres : Pennsylvania, Berkeley, Chicago, Virginia, Austin and Columbia. The new context by the late 1980s saw an interest for the first time from the three great Ivy League institutions : Harvard, Princeton and Yale. None of these had employed a historian of India. This would be the next step. 
The problem however lay in the persistent Anglophilia of these great institutions, as well as the richer liberal arts colleges. Their natural reflex was hence to recruit historians of India in Oxford and Cambridge, which they imagined were their trans-Atlantic counterparts. This American demand was to give a new lease of life to the "Cambridge School" which thus became a form of branding for export. The exception was Princeton, which - possibly on account of the « culturalist " preferences of scholars such as Robert Darnton and Natalie Zemon Davis - came to settle for the newly reminted version of Subaltern Studies. The foundation for a duopoly had been laid, and the argument was played out in public. In effect, then, the Princeton-based Gyan Prakash argued that the future of Indian studies in the United States (and, implicitly, the world) was with Subaltern Studies. This meant a series of things. First, it meant accepting Edward Said's critique of institutionalized "Orientalism " in the study of the non-West, and since it was assumed that such Orientalism was above all to be found in the study of classical and medieval cultures, it implied focusing exclusively on the colonial and postcolonial periods. Second, it meant embracing the neo-Derridean language that Spivak had popularized with vigour and enthusiasm after her translations of the French philosopher. Third, it increasingly meant coming to terms with the radical cultural critiques of the West that were emerging in India from outside the universities, and associated with problematic figures such as Ashis Nandy, himself a viscerally anti-Marxist cultural analyst and psychologist, whose early career success had been largely based precisely on his opposition to Marxism in India. In contrast, the O'Hanlon-Washbrook critique attempted to defend what they portrayed as the solid values of British radical history, as yet untainted by poststructuralism and even less by post-modernism. There was no need, in their view, to resort to ideas of radical cultural difference; rather, the old programme of the founders of Past and Present and the History Workshop Journal would do. Washbrook, it should be recalled, had increasingly begun to define himself in the 1980s as a Marxist social historian, and it was in this guise that he was offered a prestigious position to initiate the teaching of Indian history in Harvard in the late 1980s (a position which he turned down for personal reasons, and which was then later taken up by another Cambridge historian, Sugata Bose). In effect then, the Prakash vs O'Hanlon-Washbrook debate of 1990-1992 rehearsed familiar themes: from Prakash's point of view, the hegemony and disdain of the Oxbridge establishment for all sorts of colonial subjects, as well as the characteristic and empiricist British suspicion of «theory"; from the O'Hanlon-Washbrook viewpoint, solid Old World (and especially European) Marxist universalist values as opposed to an America that has become totally depoliticized (their tone here reminds one of Terry Eagleton), and where "identity " is the only remaining form of politics, in view of «the well-known hostility of American political culture to any kind of materialist or class analysis" (O'Hanlon \& Washbrook 1992 : 166). It may be worth noting the irony in this, for O'Hanlon and Washbrook were undoubtedly pressed to radicalize their critique and sharpen their polemic by none other than an American « exile» in London, Burton Stein. 
But the still larger irony should not be lost. For in the final analysis, the Atlantic did not really act as a divide but rather as a distorting mirror. On the one hand, Subaltern Studies found its way back across the ocean in ways that are subtle and interesting, often through departments of English literature or programmes of post-colonial studies in places as diverse as Portugal and Denmark. On the other hand, the newly reinvented «Cambridge School» found purchase enough to define a minority, but still appreciable, market-share in the United States. This was for two reasons. First, the logic of teaching courses required "debates" and polemics - however artificial they might be - as forms of orientation for students. Where once the debate was between "apologists » and "nationalists", it was now habitually organized into the Cambridge vs Subaltern scheme. These two names are "facts " that even one's colleagues in the most distant fields may now have heard of, and have the same status as the names of Fernand Braudel or Charles Tilly might have had some decades ago for a historian of medieval Japan seeking desperately to make conversation with his counterpart in French history. With each year, one may add names to each side of the list; some years ago, the American historian Nicholas Dirks in his book Castes of Mind launched a violent polemic against Washbrook and Bayly, accusing them in effect of being direct descendants of the robber barons of the East India Company, and found himself at once enshrined in the Subaltern pantheon (Dirks 2001). However, the problem remains that younger historians are not amenable to such easy classification. It is as if we drinkers of Saint-Emilion and Lalande-de-Pomerol were constantly asked to declare our preferences between Coca-Cola and Pepsi.

How does this work out in concrete terms? An example may be found from the world of academic journal publication regarding Indian history in the United States, which is still vastly different from what one finds on the other side of the Atlantic. In the United Kingdom, a prestigious historical review such as Past and Present almost never sends out papers to referees; it is the board of editors that is omniscient. In this case, it means that the vast majority of papers on India in the last decade and a half have been written by those closely associated with Bayly, who serves on the editorial board ; in other words, this is now pretty much the preserve of the "Cambridge School». In the United States, the situation is even more peculiar when one takes a journal such as the American Historical Review, where a publication can be quite crucial for a young and aspiring historian seeking to get "tenure». This journal tends to obtain a vast number of outside reports, as many as six or seven at times. It is here that branding is crucial. For if an essay is identified at the outset as belonging to "Subaltern Studies» - through its acknowledgements and the contents of its first three or four footnotes - it is already placed in a market niche, where other hostile referees are unlikely to be contacted. However, American academic culture also prides itself on its "pluralism ». Thus the editors of such a journal might imagine that if Subaltern Studies has $70 \%$ of the market-share, Cambridge must still have $30 \%$. It is those who are not branded who are likely to face a thorny problem 
with publication, and it is thus inevitable that they will seek anxiously to find some way of doing so. In this manner, the Subaltern-Cambridge duopolistic axis can in some instances become a self-fulfilling prophecy.

To conclude, recently, I was asked to write a comment on Peasant Pasts, a book on peasant insurgency in colonial Gujarat by an American historian of Indian origin (Chaturvedi 2007). The historian in question had initially been greatly influenced by the Marxist intellectual Robert Brenner and his work on agrarian history; he had then gone on to work in Cambridge with Bayly, whom he thanks in his preface for «his generosity and his belief in an ethos of intellectual pluralism ». However, the book, written in the form of a fast-paced narrative, is largely and obviously based in a formal sense on the model set out by the Subaltern Studies historian Shahid Amin, in his work Event, Metaphor, Memory (Amin 1995). Does this work belong then to the Cambridge School or Subaltern Studies? Decades ago, the development economist Jean Drèze recounted an anecdote to me regarding a village in northern India called "Palanpur " (a pseudonym) where at least two generations of researchers had done their fieldwork. The apocryphal anecdote had a budding researcher asking a farmer for details about the type of fertilizer he used, how much, how often, and so on. The peasant responded : "That depends ». "On what? " asked the student. "On whether you're doing your $\mathrm{MA}$ or your $\mathrm{PhD}$ ", was the response. As to whether I belong to Subaltern Studies or the Cambridge School, I suppose I am now old and uncaring enough to say neither. For the young unaffiliated scholar - and my point is that there are statistically more of these really than of any other type the answer must depend, I would suppose, on the concrete nature of supply and demand. It depends in short on whether the question is being asked in Cambridge, Yale or Chicago. In Paris, or better still in Aubervilliers, they still might not care.

\author{
University of California \\ Department of history, Los Angeles (USA) \\ subrahma@history.ucla.edu
}

MOTS CLES/KEYWORDS: études postcoloniales/postcolonial studies - subaltern studies - histoire de l'Asie du Sud/South Asian history - École de Cambridge/Cambridge school. 
Amin, Shahid

1995 Event, Metaphor, Memory. Chauri Chaura, 1922-1992. Berkeley, University of California Press.

\section{Bayly, Christopher Alan}

1988 "Rallying around the Subaltern ", Journal of Peasant Studies 16 (1) : 110-120.

\section{Chakrabarty, Dipesh}

2000 «Subaltern Studies and Postcolonial Historiography", Nepantla 1 (1) : 9-32.

\section{Chaturvedi, Vinayak}

2007 Peasant Pasts. History and Memory in Western India. Berkeley, University of California Press.

\section{Cohn, Bernard S.}

1985 "The Command of Language and the Language of Command", in Subaltern Studies 4 : Writings on South Asian History and Society. Ed. by Ranajit Guha. Delhi, Oxford University Press : 276-329.

\section{Dirks, Nicholas B.}

2001 Castes of Mind. Colonialism and the Making of Modern India. Princeton, Princeton University Press.

Habib, Irfan

1995 «Gandhi and the National

Movement ", Social Scientist 23 (4-6) : 3-15.

\section{O'Hanlon, Rosalind}

1988 « Recovering the Subject: Subaltern Studies and Histories of Resistance in Colonial South Asia ", Modern Asian Studies 22 (1) : 189-224.
O'Hanlon, Rosalind \& David Washbrook

1992 "After Orientalism : Culture, Criticism, and Politics in the Third World", Comparative Studies in Society and History 34 (1) : 141-167.

\section{Prakash, Gyan}

1990 «Writing Post-Orientalist Histories of the Third World : Perspectives from Indian Historiography ", Comparative Studies in Society and History 32 (2) : 383-408.

1992 "Can the "Subaltern" Ride? A Reply to O'Hanlon and Washbrook", Comparative Studies in Society and History 34 (1) : 168-184.

1994 "Subaltern Studies as Postcolonial Criticism ", The American Historical Review 99 (5) : 1475-1490.

\section{Singh, Sangeeta et al.}

1984 "Subaltern Studies II : A Review Article ", Social Scientist 12 (10) : 2-41.

\section{Stein, Burton}

1985 "Notes on "Peasant Insurgency" in Colonial Mysore : Event and Process", South Asia Research 5 (1) : 11-27.

\section{Subrahmanyam, Sanjay}

2000 «Parler pour autrui », L'Homme 156 : 87-97.

2002 «Making Sense of Indian

Historiography ", The Indian Economic and Social History Review 39 (2-3) : 121-130.

\section{Thomas, Trudelle} 1989 «Demystifying the Job Search : A Guide for Candidates ", College Composition and Communication 40 (3) : 312-327. 
Sanjay Subrahmanyam, One for the Money, Two for the Show. À propos des études postcoloniales et de l'histoire de l'Asie du Sud. - Cet essai a pour but de tracer l'évolution des grandes tendances dans l'historiographie sur l'Asie du Sud au cours du quart de siècle passé, se concentrant sur l'axe transatlantique. Lélévation et la transformation des subaltern studies depuis le début des années 1980 a posé un défi important à l'organisation institutionnelle de l'histoire indienne, conduisant par la suite à la redéfinition d'une Cambridge School très différente de ce qui avait existé dans les années 1970. En outre, les effets de la libéralisation économique en Inde et l'importance croissante d'une diaspora indienne aux USA ont entrainné une nouvelle situation du marché. L'essai est ainsi écrit par un participant-observateur, et la tentative est de mettre en rapport des questions épistémologiques à une application du modèle du duopole associé aux analystes tels que Cournot.
Sanjay Subrahmanyam, One for the Money, Two for the Show. On Postcolonial Studies and South Asian History. - This essay traces the evolution of trends in the historiography on South Asia over the past quarter-century, focusing on the trans-Atlantic axis. The rise and transformation of subaltern studies from the early 1980s, it is argued, posed a major challenge to the institutional organization of South Asian history, leading eventually in turn to the redefinition of a "Cambridge School" quite different from that which had existed in the 1970s. Furthermore, the effects of economic liberalization in India and the growing importance of a South Asian diaspora in the US, have led to an entirely new market situation. The essay is thus a participantobserver's attempt to relate questions of epistemology to an application of the model of duopoly associated with analysts such as Cournot. 